\title{
First report of the alien species Trichopodus trichopterus (Pallas, 1770) in the state of Ceará, Brazil
}

\author{
C. A. S. Rodrigues-Filho ${ }^{a *}$, R. C. Gurgel-Lourenço ${ }^{b}$ and J. I. Sánchez-Botero ${ }^{c}$ \\ aPrograma de Pós-graduação em Ecologia, Instituto Nacional de Pesquisas da Amazônia - INPA, Avenida André Araújo, \\ 2936, CEP 69060-001, Amazonas, AM, Brazil \\ 'Instituto de Ciências do Mar - LABOMAR, Universidade Federal do Ceará - UFC, Avenida Abolição, 3207, \\ CEP 60165-081, Fortaleza, CE, Brazil \\ 'Departamento de Biologia, Universidade Federal do Ceará - UFC, Campus do Pici, Avenida Mister Hull, 2977, \\ CEP 60455-760, Fortaleza, CE, Brazil \\ *e-mail: carlosfilho918@gmail.com
}

Received: October 12, 2016 - Accepted: November 8, 2016 - Distributed: May 31, 2018

(With 2 figures)

The three-spot gourami, Trichopodus trichopterus (Pallas, 1770), is naturally distributed in Southeast Asia: Indonesia and in the Mekong river basin (Low and Lim, 2012). Under natural conditions is found in slow-flowing streams, shallow lakes and swamps with lush riparian vegetation (Rainboth, 1996), tolerates large $\mathrm{pH}$ and temperature fluctuations and low levels of dissolved oxygen due to a suprabranchial labyrinth (Low and Lim, 2012; Blank and Burggren, 2014). The juveniles eat mainly zooplankton and benthonic algae, while adults are opportunistic omnivores (Low and Lim, 2012).

Due to its usefulness in the fight against mosquito larvae and its popularity as an ornamental fish, the species has been introduced in many regions worldwide (Webb et al., 2007). The present study constitutes the second report of T. trichopterus from the Mid-Northeastern Caatinga fish ecoregion, and first report of a species of the genus Trichopodus in the state of Ceará (Northeastern Brazil).

On 16 November 2015 and 19 November 2015, specimens of T. trichopterus were captured in the Santo Anastácio (SA) reservoir during monitoring of the ecosystem conducted by the Laboratory of Aquatic Ecology (LEA/UFC). Located in the Metropolitan basin, within Federal University of Ceará (UFC), the reservoir is part of the Maranguapinho river basin (Figure 1). Following capture with a sieve among aquatic macrophytes, the

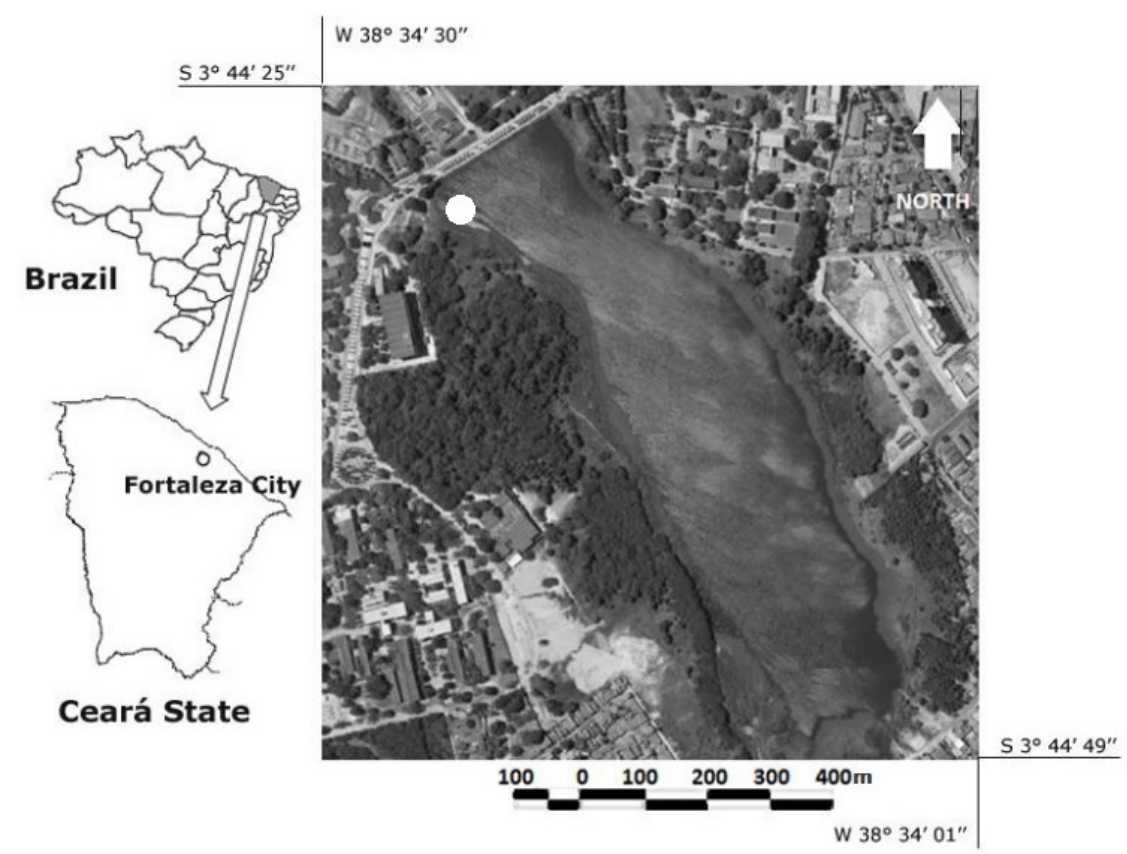

Figure 1. Geographic position (datum: WGS84) and aerial view of the Santo Anastácio (SA) reservoir showing the sampling location of T. trichopterus (white circle: $03^{\circ} 44^{\prime} 27.61^{\prime \prime} \mathrm{S} 038^{\circ} 34^{\prime} 26.44^{\prime \prime} \mathrm{W}$ ). 


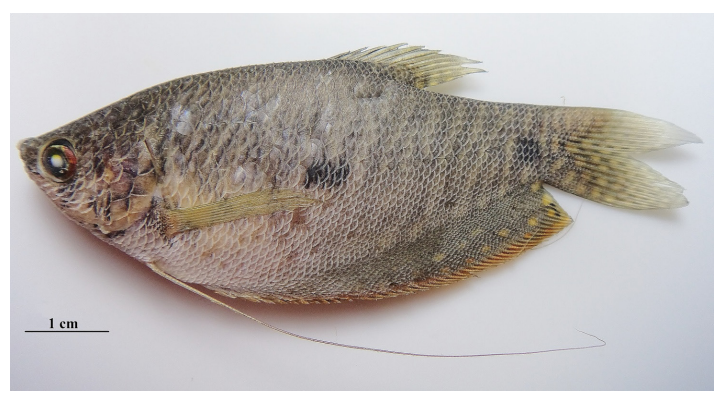

Figure 2. Specimen (61.6 mm SL) of T. trichopterus captured in the Santo Anastácio (SA) reservoir (Maranguapinho river basin). Photo credit: CASRF.

specimens were cryoanesthetized, preserved in $70 \%$ alcohol and shelved in the fish collection of Laboratory of Systematic and Evolutionary Ichthyology of the Federal University of Rio Grande do Norte (LISE/UFRN) under entry voucher number UFRN3828.

Specimens of T. trichopterus as shown in Figure 2 were captured in macrophyte beds of Eichhornia crassipes (Mart.) Solms and Paspalum repens P. J. Bergius at a depth of $40 \mathrm{~cm}$. The by-catch included the native species Hoplias malabaricus (Bloch, 1794) and Poecilia vivipara Bloch \& Schneider 1801, and the exotic species Poecilia reticulata Peters 1859 and Oreochromis niloticus (Linnaeus, 1758). Interestingly, Geheber et al. (2010) observed T. trichopterus in syntopy with species of the same genera, Poecilia caudofasciata (Regan, 1913) and Oreochromis mossambicus (Peters, 1852), and in a similar habitat (turbid water, depth less than $1 \mathrm{~m}$ ), suggesting this type of environment provides sufficient food and shelter.

The introduction of T. trichopterus in the SA reservoir is most likely recent since no previous survey has yielded any specimen, including a monthly sampling in areas with macrophytes between October 2009 and March 2010 using sieves, seine nets and gill nets (Sánchez-Botero et al., 2014). The presence of T. trichopterus is a potential threat to native species, in part because of its territorial nature, conspicuous aggressiveness (Webb et al., 2007). In view of the great adaptability of $T$. trichopterus (Geheber et al.,
2010) and the existence of an active local ornamental fish trade (the marketplace at Lagoa da Parangaba is located on the periphery of the ecosystem of the Maranguapinho river basin), the species should be monitored. If populations of T. trichopterus spread to adjacent river basins, profound changes in biodiversity may occur, with both environmental and social consequences (Vitule, 2009).

\section{References}

BLANK, T. and BURGGREN, W., 2014. Hypoxia-induced developmental plasticity of the gills and air-breathing organ of Trichopodus trichopterus. Journal of Fish Biology, vol. 84, no. 3, pp. 808-826. PMid:24502819. http://dx.doi.org/10.1111/jfb.12319.

GEHEBER, A.D., MCMAHAN, C.D. and PILLER, K.R., 2010. First record of the non-native three spot gourami, Trichogaster trichopterus (Pallas 1770) (Teleostei: Osphronemidae) in Jamaica. Aquatic Invasions, vol. 5, no. 1, suppl. 1, pp. S13-S16. http:// dx.doi.org/10.3391/ai.2010.5.S1.004.

LOW, B.W. and LIM, K.K.P., 2012 [viewed 9 October 2016]. Gouramis of the genus Trichopodus in Singapore (Actinopterygii: Perciformes: Osphronemidae). Nature in Singapore [online], vol. 5, pp. 83-93. Available from: http://lkcnhm.nus.edu.sg/nis/ bulletin2012/2012nis083-093.pdf

RAINBOTH, W.J., 1996 [viewed 9 October 2016]. Fishes of the Cambodian Mekong [online]. Rome: FAO. FAO Species Identification Field Guide for Fishery Purposes. Available from: www.fao.org/docrep/010/v8731e/v8731e00.htm

SÁNCHEZ-BOTERO, J.I., REIS, V.C., CHAVES, F.D.N. and GARCEZ, D.S., 2014 [viewed 9 October 2016]. Fish assemblage of the Santo Anastácio reservoir (Ceará state, Brazil). Boletim do Instituto de Pesca [online], vol. 40, no. 1, pp. 1-15. Available from: ftp://ftp.sp.gov.br/ftppesca/40_1_1-15.pdf

VITULE, J.R.S., 2009. Introdução de peixes em ecossistemas continentais brasileiros: revisão, comentários e sugestões de ações contra o inimigo quase invisível. Neotropical Biology and Conservation, vol. 4, no. 2, pp. 111-122. http://dx.doi.org/10.4013/ nbc.2009.42.07.

WEBB, A.C., MAUGHAN, M. and KNOTT, M., 2007 [viewed 9 October 2016]. Pest fish profiles Trichogaster trichopterus: the three spot gourami [online]. Austrália: James Cook University. Available from: https://research.jcu.edu.au/tropwater/resources/ Gourami.pdf 